Archaeological Journal

\title{
The States General of France
}

\section{Lord Henley}

To cite this article: Lord Henley (1878) The States General of France, Archaeological Journal, 35:1, 195-208, DOI: 10.1080/00665983.1878.10851827

To link to this article: http://dx.doi.org/10.1080/00665983.1878.10851827

$$
\text { 曲 Published online: 14 Jul } 2014 .
$$

Submit your article to this journal $\asymp$

Q View related articles $₫$ 


\title{
The Arcbaedogical Zattral.
}

\author{
SEPTEMBER, 1878.
}

\section{THE STATES GENERAL OF FRANCE. ${ }^{1}$}

By the LORD HENLEY.

The subject of this paper is one which should possess some interest for an Englishman. Our ancestors having had the benefit for more than six centuries of representative institutions, and having handed them down to us improved by the experience of ages, we cannot but take some interest in the early attempts of the great nation on the opposite side of the channel to obtain them.

That we have been on the whole more successful than they in the working of these institutions, may perhaps be attributable to the fact, that while we, as a nation, have had our eyes fixed on the material advantages produced by commerce and agriculture, the French have been more eager in their pursuit of military triumphs. The former objects have necessarily led to the advance of the middle and lower classes, and the possession by them of influence in the government of the country, while the pursuit of military glory has from age to age led the French to consolidate and strengthen the monarchy, and to maintain the power of the aristocracy, from whose ranks the officers of the army were almost entirely chosen.

For 300 years, however, from the early part of the 14 th to the early part of the 17 th century, representative institutions existed in France. Nuring those centuries, the States General were convoked from time to time. At one period they met with great regularity. But after the year 1614, they were allowed for 175 years to fall entirely into desuetude; and to this may be attributed in great measure, the calamities under which France has been suffering ever since the beginning of the Revolution.

1 Read in the Historical Section at the Northampton Meeting, August 2nd, 1878.

$$
\text { voL. } \mathrm{xxxy} \text { (No. 139) }
$$


The States General of France consisted of three representative bodies-one for each of the estates of the realm-the Clergy - the Noblesse - and the Tiers Etat.

The Clergy were represented by the Princes of the Church, as well as by the inferior Clergy. It will be remembered by those who are familiar with the history of the Revolution, that some of the latter were the first to obey the invitation of the Tiers Etat to the other two orders to deliberate in common with them.

The Nobility of France was nearly the most ancient and probably the most numerous of any in Europe. The privilege of Peerage, which appears to have been attached in most instances to the possession of particular estates, did not make the Peers a separate body in the States General-they elected and sat with the rest of the Noblesse: Occasionally the Kings of France used to summon great Councils, composed of Peers; and they had also the right of sitting in the Parliament of Paris, and the various Parliaments of the provinces to which they belonged. These bodies, however, were totally distinct from the States General which we are now considering.

It seems doubtful whether the "Tiers Etat," "The Third Estate,"_- "The People," had formed a part of any National Assembly in France before they were called to attend the States General, convoked by Phillip the Fair, in 1302. The term "Tiers Etat" was not then in use, and did not become so until the year 1484, at the time of the Great States General, held at Tours in that year. Before that the representatives of the people were designated as "les bonnes villes," "les bourgeois et habitants," "les communantés," and "le peuple." In the records of the States General, of 1484, two commissioners of each order are spoken of as "duos ecclesiasticos," "duos nobiles et duos tertii status." This is the first mention in French history of the Tiers Etat.

As to what the Tiers Etat was, it is not necessary for me to say much. Perhaps I may bs allowed to borrow M. Guizot's definition of it :-

"There have," says he, "been municipal bodies over all Europe. It is in France alone that there has been really a third estate of overwhelming power. It was 
during the French Revolution of 1789, the greatest surely that has ever happened, that the third estate of the realm attained its full influence; and it is in France alone that a man of the highest ability, speaking with a strong feeling of popular pride, has been able to reply to the question: 'What is the Tiers Etat?' It is everything."

I propose to take a rapid glance at the principal meetings of the States General between their commencement in 1302, and their last meeting in 1614 . Their last, that is to say, before the meeting of those memorable States General in 1789 , which were the immediate precursors of the Revolution. It is not my purpose to touch upon these, as the consideration of their proceedings would require a paper far longer than that which I have now the honour to lay before you ; and would perhaps lead us into the discussion of modern politics, rather than into that of mediæval history to which I propose strictly to confine myself.

The first convocation then of the States General carries us at once into the midst of one of those quarrels between Pope and King, of which mediæval history is full. The Pope was Boniface VIII., a Pontiff inferior to none in ambition and pride, but although cunning, deficient in sound wisdom and statesmanship. His predecessor, Celestin V., sketched his character in a few strokes: "You attain the Papacy like a fox, you will reign like a lion, and you will die like a dog."

Phillip the Fair, a grasping, avaricious monarch, quarrelled with him on the usual subject - the collation to benefices and the power of the State to tax the clergy. Phillip convoked the States General, at Paris, for the 28th March, 1302. They met in the Church of Notre Dame. The King was present, the princes of the blood, and the great feudal barons of France. The clergy were but scantily represented. They either feared the Pope, or disliked to take part in an assembly which was convoked expressly to oppose him. The deputies of the people occupied one side of the Church in great numbers. Phillip's object, however, in allowing them to take part in the Council, was to obtain their support, of which he considered himself certain, in opposing the Pope. He 
had no intention of granting to the people the right of taking part in the government of the country by their representatives. The pressure of the people in the great Council of the Nation (which now for the first time was called States General), began on the occasion we are considering. In England the Commons had been called to take their share in the Parliaments some half century before, and Phillip was imitating his neighbours in summoning them. In England the assemblies were continued under the name of Parliaments - in France, under that of States General. The body now convoked supported the King in his quarrel with the Pope, which only ended with the death of the latter in the following year, 1303.

In the year 1317, Phillip the Long convoked the States General for the purpose of declaring the Salic Law, by which females were excluded from the throne-the law of France. From the time of Huques Capet (987), there had been no failure of male heirs to the throne, but the Salic Law had never been formally proclaimed. Louis le Hutin bad died in 1316, leaving a single daughter, and his second wife Clemence enceinte. It was decided that if she gave birth to a son, Phillip should be Regent for eighteen years; if to a daughter, he should at once become King. A boy, Jean I., was born, who lived but five days, and Phillip was crowned at Reims. He immediately convoked the States General, who declared that "the laws and custom inviolably observed amongst the French, excluded females from the crown." Phillip died in 1322, leaving only daughters, and was succeeded by his brother Charles, who died in 1328, also leaving only daughters. On his death, Edward the III., of England, put in his claim to the crown of France, as grandson of Phillip the Fair, by his mother Isabella, and this led to the long wars between England and France.

Of the next meeting of the States General, under Phillip VI., but very slight record remains. They voted "that no tax could be levied on the people unless some urgent necessity or evident utility required it." Phillip was more anxious to govern as a feudal, than as a constitutional monarch, and the necessity for opposing the invasions of Edward III., forced him to seek the assistance of the great feuclal barons of the kingdom, who were 
in those ages better able to assist him in raising troops, than the representatives of the people.

-We now come to the reign of King John, who was forced to make head against the troubles occasioned by the English invasions. Passing over one assembly, of whose proceedings no record remains, we arrive at the period at which the King, unable by the royal power alone to raise either men or money, was obliged to have recourse to the Nation. He assembled the States at Paris, November 30th, 1355. These States represented only the northern provinces of France, and were called those of the Langue d'Oil, which was separated by the Dordogne and the Garonne from the Langue d'Oc, which contained the southern provinces. This portion of the kingdom had a distinct assembly of its own.

The assembly which we are considering did not claim for itself the right to govern the nation. It kept two objects in view, the defence of France against the incursions of the English, and the limitation of the power of the crown, the excesses of which had caused much discontent in the country.

The three estates met on the 5th December, 1355, in the great hall of the Parliament at Paris. Pierre de la Foret, Archbishop of Rouen and Chancellor of France, asked them in the king's name "to deliberate, and to grant the king a subsidy which might suffice for the expenses of the war," the king on his part undertaking to coin good and durable money in place of the debased coin which was then in circulation. The session did not last more than a week. The States voted a levy of 30,000 men yearly, and a subsidy of 5,000,000 francs to be levied on all people of whatever condition, churchmen, nobles and others; and the Gabelle or Salt tax over the whole kingdom of France.

Unfortunately at that time representative government was so little understood that it was found easier to vote taxes than to collect them ; and the States, after seeing their authority set at nought, and disturbances occasioned by the collection of the taxes in various parts of the kingdom, were obliged to make considerable modifications in the laws which they had at first assented to.

After King John had been taken prisoner at the battle 
of Poitiers, his eldest son Charles, who then for the first time assumed the title of Dauphin, on the annexation of Dauphine to France, convoked the Northern States at Paris. They met on the 17th November, 1356, in the great hall of the Parliament. "Never," says the Chronicle, "had been seen a more numerous assembly or one composed of wiser men." The principal clergy were all present; the noblesse had lost too many of their numbers to admit of their being very fully represented There were 400 deputies from towns. The whole assembly numbered 800 .

The three orders attempted at first to deliberate in separate chambers, but finding this inconvenient they chose commissioners from each order, who were to deliberate in common and report the results to the order which each represented.

They demanded the dismissal of twenty-two of the principal officers of state who were accused of having taken part, for their own benefit, in the abuses then existing in the government, and of having concealed from the king the truth with respect to the sufferings of the people. The damphin, who was young and inexperienced, was somewhat surprised at the further demand of the States, who required that deputies should be sent through the provinces, under the name of reformers, for the purpose of repressing the malversations of the royal officers, and that twenty-eight delegates, chosen from the three orders, should be constantly placed about the prince " with powers to act and to order everything with respect to the kingdom as if it were the king himself, as well as to appoint publick officers as for other matters." By taking this course the States were seeking to deprive the Crown of the government of the country, and to assume it themselves.

The Dauphin had no resource but to gain time, which he did by asking how much money the States proposed to grant him ; and during the delay thus occasioned, he found himself in such straits, that he was obliged to have recourse to an expedient, very common with mediæval sovereigng - that of debasing the coin. This led to the disturbances in Paris, under Etienne Marcel, which continued till his death in 1358. 
With regard to the part taken by the States General in these events, I cannot do better than quote the opinion of M. Guizot :-

"One important result was gained to France by the States General of the 14th century; the principal of the right of the nation to take part in its affairs, and to pass judgment upon its government when led astray, or incapable of performing its functions. Until then, in the 13th and the beginning of the 14th centuries, the States General had only been a momentary expedient, to which royalty had had recourse, for the purpose of resolving some special question, or of escaping from some serious difficulty. From King John's time, the States General became one of the principles of national right. A principle which did not disappear, although it remained without application, and the prestige of which survived even while the principle itself was in abeyance. Faith and hope have a great share in the life of nations, as well as of individuals. Begun in 1355, the States General of France were found still in existence in 1789 . I hope that after such a long trial, their checks and their errors will be no more fatal to them in our days than they were in those of which we have been treating."

To these reflections of M. Guizot we may add the remark, that had the French persevered with their States General, as our ancestors did with their Parliament, and not allowed them to fall into desuetude, as they did for 175 years, from 1614 to 1789 , they might have avoided the dreadful catastrophe of the latter year, which was owing in great measure to the fact, that in France some remains of the feudal system, unmitigated by representative institutions, had continued to exist nearly to the end of the 18th century.

Charles V. had recourse three times, once in 1367 , and twice in 1369, to the States General. In one of these assemblies, the King himself rose to say that, "If they saw that he had done anything which he onght not to do, they should tell him, and he would correct what he had done, for there was still time to repair it, if he had done too much or too little."

The object of the assembling of the States on that accasion was, for the King to receive, as suzeraine, the 
complaints of the Barons of Acquitaine, respecting the government of the Black Prince, which had become insupportable to them.

In the early part of the 15 th century, Charles VII. frequently called together the States General of the two divisions of his kingdom. The object of their meetings being principally to raise men and money, for the purpose of driving the English out of his country, which he eventually succeeded in doing.

In 1468, Louis XI., thrown into difficulties by the intrigues of his great vassal, the Duke of Brittany, called together the States General at Tours, Twenty-eight seigneurs, the representatives of many others who could not attend, and 192 deputies, elected by sixty-four towns, were present. The Chancellor, Juvenal des Ursins, set forth in the presence of the King the objects of their meeting. These were :

1st.-To settle the differences between the King and M. Charles, his brother, as to the Duchy of Normandy, and the apanage of the said M. Charles.

2.-To take into consideration the attacks which the Duke of Brittany had made upon the King, in taking his subjects and his towns, and in making war upon him.

3rd.-To consider the intrigues of the Duke of Brittany with the English, in inviting them to invade France, and in sarrendering to them towns in his duchy.

Upon all these points the States supported the Crown. They did not press their constitutional rights in taking part in the government of the country, but they showed patriotism and wisdom in maintaining the integrity of the country against the intrigues of feudal ambition, and in defending it from a foreign enemy.

Anne de Beaujeu, Regent of France during the minority of Charles VIII., called the States General together, in January, 1484, at Tours. They met in the great hall of the Archiepiscopal palace. Around the throne of the King sat 284 deputies. "For the first time," says M. Picot, "the whole of France was represented. Flanders alone did not send its deputies till the end of the session; but Provence, Rousillon, Burgundy, and Dauphine hastened to join their representatives to 
those of the provinces which had been longest united to the Crown."

Such was the union which existed between the various estates of the realm at this time, that a difference was observed between the elections for these States General and those for the preceding ones. Formerly each order had chosen deputies from its own ranks-and from its own ranks alone. In these elections, says the same author: "In most of the towns they proceeded in common to the choice of their deputies. The Clergy, the Noblesse, and the Citizens, who arrived at Tours, were not the exclusive representatives of the Clergy, the Noblesse, or the People. They united in the person of each, the summons to any of the three orders."

After having examined the cahiers, the papers on which the requirements and grievances of the constituencies were written, each order appointed a committee of twelve, to deliberate in common with like committees of the other two orders. This united body of thirty-six presented their report by the voice of their President, John Masselin. They kept steadily in view the object of a great political reform -a free, but a legal system of government. The States deliberated on the question of the composition of the King's Council, the most important that could be considered in a country where representative Government so rarely came into action. They then considered the question of taxation. The Crown asked more than the States were willing to grant. At length, after much discussion, they voted the taille for two years, resolving to meet again at the end of that time for the purpose of diminishing or increasing it, as occasion might require.

In this the States appeared to take their proper position in the government of the country. It was however attacked by the Court party. The Chancellor, Guillaume de Rochefort, told the States that the sum which they had voted, 1,200,000 francs, was not sufficient for the purposes of the Government, and asked for 300,000 more. He also passed over the limitation of the taille to two years. "While the Chancellor was speaking," says the President Masselin, "many of the more independent members interrupted him; and there VOL. XXXV. 
was some murmuring heard in the hall, because he appeared to ignore in his speech the power and liberty of the people." At last, after much discussion, the States persisted in their vote of $1,200,000$ francs for two years but added to it a single sum of 300,000 francs on the King's accession, and to defray the expenses of his coronation.

After violent debates, and much contention between the King's Council and the States, the latter were at length terminated by an expedient which was attempted with signal ill-success three centuries later :-

"On the 14th of March, the deputies were somewhat surprised, on entering the hall in which they sat, to find it entirely dismantled. Carpets, hangings, benches, writing table, all had been carried away. So fully did the Government look upon the Session as finished." The deputies had not the resolution of their successors in 1789 , when in similar circumstances they adjourned to the tennis court, and declared their sittings permanent. They quietly returned to their provinces, praying that their labours might turn out advantageous to the country.

In the year 1506, Louis XII. called the States General together at Tours, and opened the Session himself. Surrounded by the archbishops, all the princes of the blood, and other seigneurs and barons of the kingdom, he ordered the deputies of the States to be admitted.

On their entry, the President, Thomas Bricot, far from setting forth any grievances, contented himself with recounting the benefits which the country had received from the King's government. He ended by conferring upon the King the title of Father of his People. Loud applauses followed these words. A general emotion seized the assembly; even the King himself shed tears on hearing the title which history and posterity would ever attach to his name.

The business of the Assembly was the marriage of the King's only daughter Claude, to Francis of Angoulesme, afterwards Francis I. Francis was then twelve and Claude seven years of age.

We now approach the times of the Reformation. In consequence of the troubles which attended this great 
religious revolution, Francis II. called together the States General at Meaux.

The elections of the deputies were very stormy. The Guises employed all the powers of the government on behalf of the Catholic party. The Protestants appealed to the love of liberty, to religious feeling, and to the wish for local independence on the part of the constituencies. A royal edict enjoined all provincial authorities to take care that no Protestants were elected. These instructions were in most cases successfully carried out. One morning, however, a courier reached the Duke of Guise with a letter from the Comte de Villars, the governor of Languedoc, informing him that all the deputies of that province belonged to the new religion, or were well disposed to it. The governor was very sorry that he could not prevent their election, but the majority of votes had prevailed. There was not a moment to be lost. "The letter," says M. Picot, "was no sooner received than people were sent to meet those deputies, for the purpose of sending them where they could do neither good nor harm." The deputies fortunately escaped this ambuscade and arrived safe and sound at Orleans, but their cahiers were confiscated, and they themselves kept under supervision until the king's death put an end to their danger.

These States General were continued after the accession of Charles IX., and adjourned to Pontoise, where they confirmed the declaration of the young king, placing the government of France in the hands of his mother, Catherine de Medicis, but without giving her the title of Regent. The king of Navarre was present as lieutenantgeneral of the kingdom, and twenty-five members of the States were chosen to form the king's Council.

During the troubles occasioned by the accession of Henry IV., he called the States General together at Tours for the month of March 1590, but Cardinal Cajetan, the legate of Pope Sixtus V., forbid their assembly, and excommunicated all bishops who should attend it.

The opponents of the king, the Chiefs of the League, called the States General together on the 26th of January, 1593. They met in the great hall of the Louvre at Paris. They were opened by the Duc de Mayenne, the military Chief of the League, with all the pomp of royalty. He 
was however so ill at ease, in the position which he had assumed, that his voice could scarcely be heard in pronouncing the opening speech. 128 deputies had been elected, but only 50 attended the first sitting.

Very violent debates took place upon the question whether any conference should be held between the friends of the king, who was still a Protestant, and the States of the League, who were acting entirely upon the Catholic interest. The three orders deliberated separately. The clergy as a body, both prelates and popular preachers, were for the Spanish section of the league which. headed by Phillip II. of Spain, was for holding no terms with Henry IV., for abolishing the Salic law in France, and for placing Isabella, the daughter of the Spanish king, and Elizabeth, daughter of Henri II. of France, who was to be married to the Duke of Guise, on the throne of France. There were but few nobles in these States General. Most of them were with Henry IV., and says M. Picot, "gained lasting honor by being the first to see in what the future prosperity of France consisted." The Tiers-Etat were divided, some being fanatical leaguers and ready to follow Phillip II., others being attached to what was called the French league, in contradistinction to the Spanish, and prepared to accept Henry IV. as kin of France, provided he would become a Catholic. The Duc de Mayenne used every effort, even to personal canvassing, to secure the support of the deputies as they arrived in Paris for the party of the league.

All his exertions, however, even when supported by the money and troops of Phillip, were unavailing to stem the tide which was beginning to run in favour of peace and of legitimacy, as represented by Henry IV. "The wind," says M. Guizot, "blew no longer in the sails of the league." Their partisans gradually fell away, and the citizens of Paris used every effort to obtain peace. Some of the militia talked of raising barricades, and two of the most popular preachers of the league were hooted in the streets of Paris.

Soon after these events, early in the year 1593, Henry determined to secure peace for his country by becoming a Catholic, and on the 25 th of July was formally received into the bosom of the Roman Church. Even after this 
the Duc de Mayenne attempted to keep up the spirit of the league in the States General. He induced them to adopt the resolutions of the Council of Trent, and on proroguing them, made them promise to re-assemble on the expiry of the truce of three months, which he had made with Henry - a promise which they readily gave as they had been in the receipt of very handsome salaries, both from their own constituencies, and from Phillip of Spain.

The States of the League, however, never re-assembled. Henry succeeded in gaining the hearts of his subjects and in showing himself to be one of the greatest kings who had ever sat on the throne of France. The States General did not meet again until the last occasion, of which we have now to treat, that of the year 1614, when they were called together under the regency of Mary de Medicis, at Sens, on September 16th, to deliberate on the subject of the two proposed Spanish marriages; that of the young king Louis XIII. to Anne of Austria, eldest daughter of Phillip III. of Spain ; and that of Phillip Infant of Spain, afterwards Phillip IV. to Elizabeth of France, sister of Louis XIII.

These marriages were not looked upon very favourably by a large party in France, as uniting the country too closely to Spain. The catholicism of the latter country was of a much narrower and more submissive description than that of France, where the liberty and independence of the Gallican Church had always been maintained. The States General were looked upon as the only resource in this difficulty. They met at Sens on the 20th of October, 1614, and were opened by the young king Louis XIII. in person. The clergy sent 140 members, the noblesse 132, the Tiers-Etat 192.

These States have left but little mark in history. The principal fact in connection with them was the entry into public life for the first time of a man destined for some years to bear on his own shoulders the whole weight of the government, and to contribute in a great degree to rendering the monarchy of France absolute. Armand Jean du Plessis de Richelieu, Bishop of Luçon, was at this time aged only twenty-eight years. He was doubly returned to the States General of 1614, being 
elected as their representative, both by the clergy of Loudon and by that of Poitou. In his administration of the affairs of France, he dispensed entirely with States General. This policy was copied by his successors for 175 years, dating from 1614, and they were never again convoked. The country was governed entirely by the king and by the local parliaments, servile bodies in which no traces of popular representation existed. I do not propose, for the reason which I have before stated, to enter into the history of the States General of 1789 .

We have glanced at the States General frcm their first institution in 1302, to their cessation in 1614. We have seen them taking part in quarrels between the Pope and King, in feudal strifes between the King and his vassals, in the internal government of the country and in its defence against foreign invaders. We have watched their action while the country was agitated by the convulsion of the reformation, and while it was torn by civil war. We have always found the great council of the nation loyal, patriotic, and economical-let us hope that the great nation whose history we have been considering may, at length, after many changes and misfortunes, have found a representative system, by means of which the many good qualities which belong to her national character, may produce their proper effect in her actions, both as an important member of the European family of nations, and as one of the leading countries of the civilized world. 